\title{
Okul öncesi çocuklarının öğrenme merkezlerinde geçirdikleri süreler ile sosyal becerileri arasındaki ilişkinin incelenmesi
}

\section{Examining the relationship between preschool children's time spent in learning centers and their social skills}

\author{
Oya Ramazan ${ }^{1}$, Hamdi Özdemir ${ }^{2}$
}

\section{Makale Geçmişi \\ Geliş : :11 Mayıs 2020 \\ Düzeltme : 27 Temmuz 2020 \\ Kabul : 12 Eylül 2020}

\section{Makale Türü}

Araștrma Makalesi

\section{Article History \\ Received : 11 May 2020 \\ Revised : 27 July 2020 \\ Accepted : 12 September 2020}

\section{Article Type}

Research Article

\begin{abstract}
Öz: Bu araştırmada okul öncesi kurumlarına devam eden 56-72 aylık çocukların öğrenme merkezlerinde geçirdikleri sürelerle sosyal becerilerinin ilişkisinin ortaya konulması amaçlanmıştır. Bu doğrultuda çocukların öğrenme merkezlerinde geçirdikleri süreler, tercih ettikleri farklı öğrenme merkezleri sayıları ve öğrenme merkezlerindeki akran sayıları ile sosyal becerileri arasındaki ilişkinin belirlenmesi hedeflenmiştir. Araştırmada ilişkisel tarama yöntemi kullanılmıştır. Verileri elde etmek için 25 kişilik çalışma grubuna öğrenme merkezleri gözlem formu ve okul öncesi sosyal beceri değerlendirme ölçeği öğretmen formu uygulanmıştır. Çocukların sanat merkezi süreleri ile başlangıç becerileri arasında orta düzeyde ve pozitif yönde, müzik merkezi süreleri ile arkadaşlık becerileri arasında orta düzeyde ve negatif yönde anlamlı ilişki bulunmuştur. Merkezdeki akran sayıları ile akademik becerileri arasında orta düzeyde ve pozitif yönde; tercih ettikleri merkez çeşidi sayısı ile duyguları yönetme becerileri arasında orta düzeyde ve negatif yönde anlamlı ilişki olduğu sonucuna ulaşılmıştır.
\end{abstract}

Anahtar Kelimeler: Okul öncesi, Sosyal beceri, Öğrenme merkezleri

Abstract: In this study, it is aimed to reveal the relationship between the social skills of 56-72 monthold children and the time they spend in learning centers. Accordingly, it is also aimed to determine the relationship between the children time spent in the learning centers, the number of different learning centers they prefer, the number of peers in the learning centers and their social skills. The study was carried out with the correlational research. In order to obtain the data, a learning center observation form and pre-school social skills assessment scale - teacher form were given to the study group of 25 . The research found out a moderate and positive correlation between children's time spent in art center and beginner's skills, a moderate and negative correlation between the time spent in music center and friendship skills. It has been concluded that there is a moderate and negative correlation between the number of peers in the center and their academic skills, and moderate and positive correlation between the number of centers they prefer and their emotion management skills.

Keywords: Preschool, Social skills, Learning centers 


\section{SUMMARY}

\section{Introduction}

Avcioğlu (2007) stated that many social skills are gained unconsciously in the circle of friends and within the family. Children learn social skills by modeling and observing their surroundings. Some researches state that dramatic plays are related to social skills and also social skill training programs and interactive buildingbuilding games improve the social skills of children (Aslan, 2008; Durualp and Aral, 2010; Ia Greca and Santogrossi, 1980; Kara and Çam, 2007; Kazdin, Matson and Esveldt-Dawson, 1984; Legoff and Sherman, 2006; O ' Connor and Stagnitti, 2011; Spence, 2003). In addition to educational programs given to children, social skills develop through free play. In preschool period, children can spend time with their peers at the learning centers during the free time activities included in the program. Learning centers are defined as playgrounds consisting of different materials and they are separated from each other in preschool education institutions. When children come to these centers, continue their activities in these centers in line with their interests and wishes. The main centers that should be present in preschool classes are listed as blocks, books, music, arts, science and dramatic play centers (Milli Ĕ̆itim Bakanlığı [MEB], 2013).

\section{Method}

Correlational research was designed. The study group of the research consists of 25 children determined by the easily accessible sampling method in the 2017-2018 Academic Year. While determining the study group, five kindergartens in Istanbul province were selected. In order for teachers to make their observations in a healthy way, five students from each class were randomly selected. To collect data, The Learning Centers Observation Form and the Preschool Social Skill Assessment Scale - Teacher Form were used. Learning Centers Observation Form (ÖMGF) was developed by researchers in order to record the centers preferred by children during their free play periods, the time they spent in the centers and the number of peers at the centers during those periods. Preschool Social Skill Assessment Scale (PSSAS) was developed to evaluate social skills for 36-72 month-old children by Ömeroğlu et al. (2014). Spearman Brown Correlation Test was performed to analyze the data.

\section{Results}

The most frequent learning center for children is the dramatic play center with 352,50 minutes $(39,88 \%)$, and then the block center with 295,00 minutes (33.38\%). Science center was observed to be the least preferred center with 7,75 minutes $(0.88 \%)$. A positive and moderately significant correlation was found between beginner's skills scores and the time spent in the arts center $(\mathrm{r}=, 409 ; \mathrm{p}<.05)$. A negative and moderately significant correlation was found between friendship skills and the time spent in the music center. $(\mathrm{r}=-, 482 ; \mathrm{p}<.05)$. No significant relationship was found in other dimensions. A positive and moderately significant correlation was found between children's academic skills and peer numbers in learning centers $(\mathrm{r}=, 489 ; \mathrm{p}<.05)$. There was a negative and moderately significant correlation between emotion management skills and the number of learning centers preferred by children $(\mathrm{r}=-, 403 ; \mathrm{p}<.05)$. 


\section{Conclusion and Discussion}

When the time spent children in the learning centers of children and their social skills are studied, it was found out that there was a positive correlation between the beginner's skills and the time spent in the arts center. According to Blatt-Gross (2011), children working at a common table in art events, interacting in the distribution of materials or exchanging with each other, require a good social interaction. In addition, he states that children have long conversations with each other about colors and shapes during their art activities. They show important indicators in terms of social skills such as asking for permission during the use of their friends' materials, and sometimes they give pictures to each other. However, no relationship was found in the dramatic game center and block center where the number of peers was higher and preferred more. Children generally exhibit aggressive attitudes in socio-dramatic games, especially boys (Jarvis, 2007; Dunn \& Hughes, 2001, cited by Hart \& Tannock, 2013). According to this, it is an unexpected result that there is no opposite relationship with the starting skills and the time spent in the dramatic game center and block center. A negative correlation was found between the time spent in the music center and the friendship skills of the children. The music center is defined as the center where activities are carried out to increase children's sound, movement and rhythm skills in literature (Özdemir Beceren, 2016). Considering the definitions, it can be said that the number of peers and interaction is less in the music centers where children spend free time. They spend more time individually with the materials and therefore their friendship skills scores are lower.

A positive correlation was found between the number of peers in the centers where children spend time and their academic skills. Uyanık and Kandır (2010) briefly describes early academic skills as literacy and math skills for preschoolers. In terms of social skills, most of these skills include language and communication skills. It is possible to claim that as the number of peers in the centers attended by the child increases, the child's greater exposure to these experiences plays a role in improving their academic skills. Ertürk Karaca, Ayranc1, and Kılıç (2016) found out in their studies, children's speaking and listening skills improved by free play.

It was also observed that there is a reverse correlation between the number of center types preferred by children and their emotions management skills. Özyürek and Kılınç (2015) stated that, for children, choosing the centers where they have friends plays an important role. In the meantime, they need to learn many forms of social relationships in order to adapt to the game environment (Özdoğan, 2014). Accordingly, as the number of children's learning center choices increases, their ability to manage their emotions decreases. The reason for this may be that they are not fully included in a game group. 


\section{GİRIŞ}

Okul öncesi dönem olarak adlandırılan yaşamın ilk altı yılı gelişimsel olarak oldukça önemli bir dönemdir (Eke, 2017). Bu dönemde çocuğa verilecek firsatlar ve olumlu yetişkin desteği çocuğun yaşama en iyi şekilde hazırlanmasını sağlar, çocuktan esirgenenler ise onun yaşama hazırlanma sürecinde pek çok zorlukla karşılaşmasına neden olur (Zembat, 2001). Çocuğun sağlıklı bir şekilde büyüyebilmesi, gelişebilmesi ve öğrenmeye karşı olumlu tutumlar geliştirebilmesi için nitelikli bilişsel uyarıcıların, zengin dil etkileşimlerinin, olumlu sosyal-duygusal deneyimlerin çocuğa sunulduğu ve çocuğun bağımsızlığının desteklendiği bir çevrenin oluşturulmasına ihtiyaç vardır. Bu ise ancak sağllklı bir aile ortamında ve nitelikli bir okul öncesi eğitim kurumunda mümkün olabilir (Güleş, 2013).

Çocukların aileden sonra daha geniş bir çevrede akranlarıyla birlikte olduğu ve yaşamlarında çok önemli rol oynayan yer, okul öncesi eğitim kurumudur. Çocuk burada oyunlar oynayarak ve etkinlikler yaparak akranlarıyla daha sık iletişime geçer ve sosyal gelişimini şekillendirir. Erikson’a göre, okul öncesi dönem çocuklarında girişimcilik dürtüsüyle harekete geçerek kendilerini kanıtlama isteği doğar (Trawick-Smith, 2013) ve artık akranlarıyla sıklıkla bir araya gelme, oyun oynama, paylaşma, mücadele etme gibi ihtiyaçlar kendini gösterir (Koçyiğit, 2016); ancak akran etkileşimlerinin artması için çocukların bir takım duygusal ve sosyal becerilere sahip olmaları gerekir (Kramer, Caldarella, Christensen ve Shatzer, 2009).

Sosyal beceriler; bireyin içinde bulunduğu çevrede uygun davranışlar sergilemesini, diğerleriyle olumlu iletişim kurmasını sağlayan, sözel ve sözel olmayan davranışları içermektedir (Akfırat Önalan, 2006; Durualp ve Aral, 2011). Gresham ve Elliott (1987) sosyal becerileri, insanların diğer insanlarla etkileşim içinde olmasını ve sosyal olarak kabul görmeyen davranışlardan kaçınmalarını sağlayan, 'kabul gören öğrenilmiş davranışlar' olarak tanımlamaktadır. Yüksel’e (1998) göre sosyal beceriler, başkalarından olumlu tepkiler almaya yol açacak, duruma özgü değişebilen, gözlenebilir veya gözlenemeyen davranışlardır. Swindells ve Stagnitti (2006) ise sosyal becerileri, sosyal düşüncelerin sosyal ortamlardaki etkileşimlerde düşünce ya da davranış şeklinde yansıması olarak açıklamaktadır.

Sosyal becerilerin tanımlanmasında olduğu gibi sınıflandırılmasında da farklılıklar bulunmaktadır. Riggio (1986) sosyal becerileri; 'duygusal denetim', 'duygusal duyarlllkk', 'duygusal ifade', 'sosyal ifade', 'sosyal duyarlılık' ve 'sosyal manipülasyon' olmak üzere altı başlıkta sınıflandırmıştır. Akkök (2003) sosyal becerileri; 'ilişkiyi başlatma ve sürdürme’ becerileri, 'grupla bir işi yürütme’ becerileri, 'duygulara yönelik' beceriler, 'saldırganlık davranışı ile başa çıkma' becerileri, ‘stres durumlarıyla başa çıkma' becerileri, 'plan yapma ve problem çözme' becerileri olarak altı boyutta açıklamıştır. 
Caldarella ve Merrell (1997) ise sosyal becerileri; 'akran ilişkileri', 'kendini kontrol etme' becerileri, 'akademik' beceriler, 'uyum sağlama' becerileri ve 'kendini ifade etme' becerileri olmak üzere beş boyutta ele almıştır.

Sosyal becerileri gelişmiş çocukların iletişim becerilerinin daha yüksek olduğu; sosyal problem çözmede, sosyal yeterlilikte, akademik başarıda, arkadaşlık kurmada ve sürdürmede daha başarılı oldukları belirtilmiştir (Berk, 2013; Bierman vd., 2004). Sosyal beceri yönünden yetersiz olan çocuklar ise ileriki yıllarda sosyal ilişkilerinde problemler yaşayabilmekte; kurallara uymada ve öğretmenleriyle ilişkilerinde, akranlarıyla etkileşime geçmede ve iletişim kurmada sorunlar ortaya çıkabilmekte, kişilik ve davranış problemleri gözlenebilmektedir (Durualp ve Aral, 2011; McClelland ve Morrison, 2003). Bennet, Finn Jr. ve Cirbb Jr. (2000) kuralları tanıma, diğerlerinin bakış açılarını ve duygularını anlama, diğerlerinin haklarının olduğunu anlama, paylaşma, sırasını bekleme, başkalarının eşyalarına saygı gösterme, grubun bir parçası olma, diğerleriyle birlikte çalışma, sessizce bekleyebilme, yetişkin otoritesini tanıma, kibar olma, evden ve aileden bir süre ayrı kalabilme gibi sosyal becerilerin okula başlamadan önce çocuklara kazandırılması gerektiğini belirtmektedir.

Sosyal beceriler; çocuğun yaşına, cinsiyetine, yaşadığı yere, beraber yaşadığı kişilere, okula devam etme süresine, ailesinin sahip olduğu değerlere ve çocuğu destekleyip desteklememesine bağlı olarak değişiklik gösterebilmektedir (Acun Kapıkıran, Bora İvrendi ve Adak, 2006; Bilek, 2011; Ekinci Vural, 2006; Neslitürk, 2013). Birçok sosyal beceri arkadaş çevresinde ve aile içerisinde farkında olmadan kazanılabilmekte; çocuklar çevresindeki kişileri model alarak, gözlemleyerek sosyal becerileri öğrenebilmektedir (Avcıoğlu, 2007). Sosyal beceriler serbest oyun yoluyla da gelişmektedir. Oyun gruplarında çocukların birbirleriyle etkileşimleri onların sosyal becerilerini arttırmaktadır (Mueller ve Brenner, 1977). Oyun deneyimine sahip olmayan çocukların ise bilişsel, duygusal ve sosyal gelişimleri zarar görmektedir (Bodrova ve Leong, 2010). Kendiliğinden bu becerileri kazanamayan çocuklar için sistematik olarak sosyal beceri eğitiminin gerektiği belirtilmiştir (Bennet vd., 2000).

Günümüzde çocukların oyun yoluyla sosyalleşebilecekleri en uygun ortamlardan biri okuldur. Okul öncesi dönemde çocuklar, programda yer alan serbest zaman etkinlikleri süresince her gün öğrenme merkezlerinde akranlarılla vakit geçirebilmektedir. Öğrenme merkezleri; okul öncesi eğitim kurumlarında farklı materyalleri içeren, birbirinden ayrılmış oyun alanlarıdır. Çocuklar güne başlama zamanının ardından kendi ilgi ve istekleri doğrultusunda bu merkezlerde etkinliklerini sürdürebilmekte; istediği zaman bir merkezden diğerine geçebilmektedir. Bakanlık tarafindan sınıflarda bulunması gereken temel öğrenme merkezleri blok, kitap, müzik, sanat, fen ve dramatik 
oyun olarak sıralanmıştır (MEB, 2013). Çocukların farklı öğrenme merkezlerinde oyun oynamaları; kendini uygun şekilde ifade etme, sosyal problem çözme, yardımlaşma, paylaşma, işbirliği, başladığ1 işi sonuçlandırma konusunda kararlı olma, sorumluluk alma ve aldığı sorumluluğu yerine getirme, toplumsal cinsiyet rollerini kazanma gibi sosyal ve duygusal becerilerin gelişmesine katkı sağlaması açısından çok önemlidir (Aral, Kandır ve Can-Yaşar, 2011).

Öğrenme merkezlerinin kullanım amaçları, özellikleri ve içinde yer alan materyaller birbirinden farklıdır. Örneğin, kitap merkezi daha sessiz ve sakinken müzik ve blok merkezleri çocukların daha hareketli ve aktif oldukları merkezlerdir (Aktaş-Arnas, 2018). Öğrenme merkezlerinin farklı kullanım amaçlarının ve farklı materyallerinin çocukların sosyal etkileşimlerinde de farklılığa yol açması beklenebilir. Örneğin, dramatik oyun merkezi ve blok merkezi, çocukların daha bağımsız hareket edebildikleri merkezler olarak görülmektedir (Özyürek ve Kılınç, 2015). Yapılan bazı araştırmalarla interaktif yapı-inşa oyunlarının çocukların sosyal becerilerini arttırdığı, dramatik oyunların sosyal becerilerle ilişkili olduğu ortaya çıkarılmıştır (Aslan, 2008; Durualp ve Aral, 2010; Ia Greca ve Santogrossi, 1980; Kara ve Çam, 2007; Kazdin, Matson ve Esveldt-Dawson, 1984; Legoff ve Sherman, 2006; O'Connor ve Stagnitti, 2011; Spence, 2003). Blatt-Gros (2011) çocukların sanat etkinlikleri sırasında da materyalleri birlikte kullanabilmek için birbirleriyle olumlu ifadelerle etkileşime geçtiklerini belirtmektedir.

Yapılan araştırmalar sonucunda çocukların sosyal becerilerinin akranlarıyla oynadığı oyunlar yoluyla arttı̆̆ belirlenmiştir, ancak çocukların serbest oyun saatlerinde farklı öğrenme merkezlerinde yaptıklarının (oyun ya da etkinlik, tek başına ya da arkadaşlarıyla) sosyal becerilerle olan ilişkisine dair yeterli çalışmaya ulaşılamamıştır. Bu çalışmada okul öncesi dönem çocuklarının (56-72 aylık) öğrenme merkezlerinde geçirdikleri süreler ile sosyal becerileri arasında anlamlı bir ilişkinin olup olmadığının incelenmesi amaçlanmış ve şu sorulara yanıt aranmıştır:

1) Çocukların serbest oyun saatlerinde tercih ettikleri öğrenme merkezleri ve burada geçirdikleri ortalama süre cinsiyetlerine göre değişmekte midir?

2) Çocukların serbest oyun saatlerinde tercih ettikleri öğrenme merkezleri ve burada geçirdikleri ortalama süre yaşlarına göre değişmekte midir?

3) Çocukların sosyal beceri puanları ile öğrenme merkezlerinde geçirdikleri ortalama süreler arasında anlamlı bir ilişki var mıdır?

4) Çocukların sosyal beceri puanları ile en çok zaman geçirdikleri öğrenme merkezlerinde birlikte bulundukları akran sayıları arasında anlamlı bir ilişki var mıdır?

5) Çocukların sosyal beceri puanları ile oynamayı tercih ettikleri öğrenme merkezlerinin sayısı arasında anlamlı bir ilişki var mıdır? 


\section{YÖNTEM}

\section{Araştırma Modeli}

Nicel desendeki bu araştırmada, genel tarama modellerinden 'ilişkisel tarama' modeli kullanılmıştır. $\mathrm{Bu}$ model, iki ya da daha çok değişkenin aralarındaki ilişkiyi belirlemek amacıyla kullanılır (Büyüköztürk vd., 2018).

\section{Çalışma Grubu}

Araştırmanın çalışma grubu; 2017-2018 eğitim-öğretim yılı bahar döneminde 'kolay ulaşılabilir örnekleme' yöntemi ile saptanmış, İstanbul'un dört ilçesindeki beş devlet anaokuluna devam eden 56-72 aylık 25 çocuktan oluşmuştur. Öğretmenlerin çocukları daha doğru gözlemleyebilmeleri için her anaokulundan bir sınıf ve her sınıftan rastgele seçimle beş çocuk belirlenmiştir. 11'i kız, 14'ü erkek olan çocukların 3'ünün yaş1 56-60 ay, 11'inin 61-66 ay, 11'inin ise 67-72 ay arasındadır.

\section{Veri Toplama Araçları}

Araştırmada veri toplama amacıyla ‘Öğrenme Merkezleri Gözlem Formu’ ve ‘Okul Öncesi Sosyal Beceri Değerlendirme Ölçeği - Öğretmen Formu’ kullanılmıştır.

\section{Öğrenme merkezleri gözlem formu (ÖMGF)}

Çocukların serbest oyun saatinde öğrenme merkezlerinde geçirdikleri süreleri, en çok zaman geçirdikleri öğrenme merkezlerinde birlikte bulundukları akran sayılarını, oynamayı tercih ettikleri öğrenme merkezi sayısını kaydetmek amacıyla araştırmacılar tarafından geliştirilmiştir.

Formda, MEB'in okul öncesi eğitim sınıflarında bulunmasını zorunlu tuttuğu 6 öğrenme merkezi (blok, kitap, müzik, sanat, fen, dramatik oyun) alt alta sıralanmış, ayrıca farklı bir merkez olması durumunda kaydedilebileceği bir boşluk bırakılmıştır. Listedeki bu merkezlerin karşısına gözlenen çocuğun cinsiyetinin, merkezde oynadığı sürenin, bu süre boyunca kendisiyle birlikte merkezde oynayan akran sayısının kaydedilmesi için alanlar bırakılmıştır.

\section{Okul öncesi sosyal beceri değerlendirme ölçeği (OSBED) - öğretmen formu}

Okul Öncesi Sosyal Beceri Değerlendirme Ölçeği, 36-72 aylık çocukların sosyal becerilerini değerlendirmek amacıyla Ömeroğlu vd. tarafından geliştirilmiştir. Geçerlik çalışması kapsamında yapılan 'faktör analizi' sonucunda ölçeğin dört alt boyuttan ve toplam 49 maddeden oluştuğu belirlenmiştir: 
1-Başlangıç Becerileri (12 madde): Çocukların kolay öğrenebildikleri ve diğer sosyal becerilerin kazanılması için temel teşkil eden beceriler.

2-Akademik Beceriler (12 madde): Çocukların akademik becerilerini desteklemeye yönelik, onları ilköğretime hazırlayan ve uyumlarını kolaylaştıran beceriler.

3-Arkadaşlık Becerileri (13 madde): Çocukların olumlu akran etkileşimini geliştiren beceriler.

4-Duyguları Yönetme Becerileri (12 madde): Çocukların duygularını tanıma ve kontrol etme becerileri.

Yapılan güvenilirlik çalışması kapsamında ölçeğin Cronbach Alpha güvenilirlik katsayıları Başlangıç Becerileri alt boyutu için .89, Akademik Beceriler alt boyutu için .88, Arkadaşlık Becerileri alt boyutu için .92, Duyguları Yönetme alt boyutu için .92 olarak bulunmuştur (Ömeroğlu vd., 2014).

Ölçeğin her maddesinde yanıtlamak için 5 seçenek bulunmaktadır. Bu seçeneklerden 'hemen hemen hiç’ 1 puan, 'nadiren' 2 puan, ‘bazen' 3 puan, ‘çoğu zaman’ 4 puan ve 'hemen hemen her zaman' 5 puan olarak değerlendirilmektedir. Ölçek toplamında alınabilecek en düşük puan 49, en yüksek puan ise 245'dir (Ömeroğlu vd., 2014).

Bu araştırmada da ölçeğin güvenilirliği yeniden sınanmış; Cronbach Alpha güvenilirlik katsayılarının Başlangıç Becerileri alt boyutu için .92; Akademik Beceriler alt boyutu için .87; Arkadaşlık Becerileri alt boyutu için .93; Duyguları Yönetme Becerileri alt boyutu için .92 ve ölçeğin toplamı için .96 olduğu saptanmıştır.

\section{Verilerin Toplanmas1}

MEB'den gerekli izin alındıktan sonra veriler toplanmıştır. Öğretmenlere önce 'Öğrenme Merkezleri Gözlem Formu’ tanıtılmış, nasıl doldurulacağı anlatılmış ve bu formu çocukların öğrenme merkezlerinde vakit geçirdikleri serbest oyun zamanı boyunca doldurmaları istenmiştir. Öğretmenlerin yaptığ1 bu gözlemler ile çocukların hangi öğrenme merkezinde ne kadar süre kaldığının, vakit geçirdikleri öğrenme merkezlerinde kaç tane akranı ile birlikte olduğunun, oynamayı tercih ettikleri farklı öğrenme merkezlerinin sayısının belirlenmesi amaçlanmıştır. $\mathrm{Bu}$ nedenle formlar öğretmenler tarafindan, her çocuk için haftada bir kez olmak üzere toplamda 9 kez doldurulmuştur, yani her çocuk toplam 9 hafta (yaklaşık bir dönem boyunca) gözlenmiştir. Her çocuğun 9 hafta boyunca farklı günlerde gözlenmesine dikkat edilmiştir.

Araştırmada kullanılan 'Sosyal Beceri Değerlendirme Ölçeği (OSBED)-Öğretmen Formu' ise çocukların öğrenme merkezlerinde gözlenmesi sonuçlandıktan sonra çocukların öğretmenleri tarafindan doldurulmuştur.

Öğretmenlerin gözlemleri doğru yaptığı ve ölçekleri doğru doldurduğu varsayılmıştır. Doldurulan formlar ve ölçekler araştırmacılar tarafindan öğretmenlerden toplanmıştır. 


\section{Verilerin Çözümlenmesi}

Ölçek ve gözlem formu ile toplanan veriler istatistik paket programı SPSS v.24'e girilmiştir. Gözlem ile elde edilen verilerin (öğrenme merkezlerinde geçirilen süre, en çok zaman geçirilen merkezdeki akran sayıları) ortalamaları hesaplanmıştır. Alanyazında küçük gruplarda nonparametrik analizlerin kullanılması gerektiği belirtilmektedir (Büyüköztürk, 2018). Bu nedenle ilişki bakılan verilerin analizinde parametrik olmayan 'Spearman Korelasyon Testi' kullanılmıştır.

\section{BULGULAR}

Öğretmenlerin araştırmacılar tarafindan geliştirilmiş olan gözlem formuna bağlı kalarak yaptıkları gözlem sonucunda, çocukların serbest oyun saatlerinde tercih ettikleri öğrenme merkezleri ile burada geçirdikleri bir haftalık toplam ortalama sürelerin ve bu sürelerin yüzdelerinin cinsiyetlere ve yaşlara göre dağılımı Tablo 1 ve 2'de verilmiştir.

Tablo 1 Çocukların tercih ettikleri öğrenme merkezlerinin ve buralarda geçirdikleri ortalama sürelerin cinsiyetlerine göre dağılımı

\begin{tabular}{|c|c|c|c|}
\hline Öğrenme Merkezleri & Cinsiyet & Süre (dk) & $\%$ \\
\hline \multirow{3}{*}{ Dramatik Oyun } & $\mathrm{K}_{1 \mathrm{z}}$ & 188,21 & 52,32 \\
\hline & Erkek & 164,36 & 31,34 \\
\hline & Toplam & 352,50 & 39,88 \\
\hline \multirow{3}{*}{ Blok } & $\mathrm{K}_{12}$ & 34,21 & 9,51 \\
\hline & Erkek & 260,96 & 49,75 \\
\hline & Toplam & 295,00 & 33,38 \\
\hline \multirow{3}{*}{ Sanat } & $\mathrm{K}_{1 z}$ & 100,10 & 27,83 \\
\hline & Erkek & 58,94 & 11,23 \\
\hline & Toplam & 159,00 & 17,98 \\
\hline \multirow{3}{*}{ Müzik } & $\mathrm{K}_{12}$ & 24,31 & 6,75 \\
\hline & Erkek & 14,14 & 2,70 \\
\hline & Toplam & 38,50 & 4,35 \\
\hline \multirow{3}{*}{ Kitap } & $\mathrm{K}_{12}$ & 10,34 & 2,87 \\
\hline & Erkek & 20,86 & 3,99 \\
\hline & Toplam & 31,25 & 3,53 \\
\hline \multirow{3}{*}{ Fen } & $\mathrm{K}_{12}$ & 2,64 & 0,72 \\
\hline & Erkek & 5,18 & 0,99 \\
\hline & Toplam & 7,75 & 0,88 \\
\hline
\end{tabular}

Tablo 1'e göre, çocukların en çok vakit geçirmeyi tercih ettikleri öğrenme merkezi 352,5 dakika $(\% 39,88)$ ile dramatik oyun merkezi ve 295 dakika ile $(\% 33,38)$ blok merkezidir. Fen merkezi ise 7,75 dakika $(\% 0,88)$ ile en az tercih edilen merkez olarak belirlenmiştir. Cinsiyete göre bakıldığında kız çocukları 188,21 dakika (\%52,32) ile en çok ‘dramatik oyun’ merkezini ve 100,1 dakika (\%27,83) ile 'sanat' merkezini; erkek çocuklar ise 360,96 dakika $(\% 49,75)$ ile blok merkezini ve 164,36 dakika $(\% 31,34)$ ile dramatik oyun merkezini tercih etmiştir. 
Tablo 2 Çocukların tercih ettikleri öğrenme merkezlerinin ve buralarda geçirdikleri ortalama sürelerin yaşlarına göre dağılımı

\begin{tabular}{cccc}
\hline Öğrenme Merkezleri & Cinsiyet & Süre (dk) & \% \\
\hline \multirow{2}{*}{ Dramatik Oyun } & $56-60$ ay & 22,08 & 28,00 \\
& $61-66$ ay & 104,06 & 30,66 \\
& $67-72$ ay & 226,49 & 48,60 \\
\hline \multirow{2}{*}{ Blok } & $56-60$ ay & 40,71 & 51,60 \\
& $61-66$ ay & 99,00 & 29,18 \\
& $67-72$ ay & 155,43 & 33,35 \\
\hline \multirow{2}{*}{ Sanat } & $56-60$ ay & 12,39 & 15,70 \\
& $61-66$ ay & 83,38 & 24,58 \\
\multirow{2}{*}{ Müzik } & $67-72$ ay & 63,25 & 13,57 \\
& $56-60$ ay & 0,00 & 0,00 \\
& $61-66$ ay & 27,94 & 8,24 \\
& $67-72$ ay & 10,45 & 2,25 \\
\hline \multirow{2}{*}{ Kitap } & $56-60$ ay & 0,99 & 1,27 \\
& $61-66$ ay & 21,67 & 6,38 \\
& $67-72$ ay & 8,58 & 1,84 \\
\hline \multirow{2}{*}{ Fen } & $56-60$ ay & 2,70 & 3,42 \\
& $61-66$ ay & 3,30 & 0,97 \\
\end{tabular}

Tablo 2'deki bulgulara göre; 56-60 ay arası çocuklar 40,71 dakika $(\% 51,60)$ ile en çok blok merkezini ve ardından 22,08 dakika $(\% 28,00)$ ile dramatik oyun merkezini tercih etmiştir. 61-66 ay arasındaki çocukların 104,06 dakika $(\% 30,66)$ ile en çok dramatik oyun merkezini, 99 dakika $(\% 29,18)$ ile blok merkezini ve 83,38 dakika $(\% 24,58)$ ile sanat merkezini tercih ettikleri belirlenmiştir. 67-72 ay arasındaki çocukların ise 226,49 dakika $(\% 48,60)$ ile en çok dramatik oyun merkezinde, ardından 155,43 dakika $(\% 33,35)$ ile blok merkezinde zaman geçirdikleri saptanmıştır.

Çalışma grubunu oluşturan çocukların 'Sosyal Beceri Değerlendirme Ölçeği (OSBED)-Öğretmen Formu'ndan aldıkları toplam puan ve ölçeğin alt boyutlarından aldıkları puanlar ile öğrenme merkezlerinde geçirdikleri ortalama süreler, öğrenme merkezlerinde birlikte bulundukları akran sayıları, oynamayı tercih ettikleri farklı öğrenme merkezlerinin sayıları arasında anlamlı ilişki olup olmadığına dair bulgular Tablo 3, 4 ve 5'de sunulmuştur.

Tablo 3 Çocukların sosyal beceri puanları ile öğrenme merkezlerinde geçirdikleri süreler arasındaki pearson korelasyon testi sonuçları

\begin{tabular}{lcccccc}
\hline $\begin{array}{c}\text { Ölçek toplamı ve alt } \\
\text { boyutları }\end{array}$ & $\begin{array}{c}\text { Blok } \\
\text { Merkezi }\end{array}$ & $\begin{array}{c}\text { Kitap } \\
\text { Merkezi }\end{array}$ & $\begin{array}{c}\text { Müzik } \\
\text { Merkezi }\end{array}$ & $\begin{array}{c}\text { Sanat } \\
\text { Merkezi }\end{array}$ & $\begin{array}{c}\text { Fen } \\
\text { Merkezi }\end{array}$ & $\begin{array}{c}\text { Dramatik Oyun } \\
\text { Merkezi }\end{array}$ \\
\hline Başlangıç Becerileri & -.372 & -.109 & .022 & $.409 *$ & -.307 & .031 \\
Akademik Beceriler & -.109 & -.006 & -.345 & .162 & -.007 & .018 \\
Arkadaşlık Becerileri & -.137 & .067 & $-.482 *$ & .109 & -.034 & -.052 \\
Duyguları Yönetme & -.009 & -.078 & -.379 & .281 & -.341 & .012 \\
Becerileri & -.166 & -.058 & -.328 & .250 & -.206 & .069 \\
Ölçek Toplamı & & & & & &
\end{tabular}


Tablo 3'e bakıldığında 'Başlangıç Becerileri' alt boyut puanları ile sanat merkezinde geçirilen süreler arasında pozitif yönde, orta düzeyde anlamlı bir ilişki $(r=, 409 ; \mathrm{p}<.05)$ vardır. 'Arkadaşlık Becerileri' alt boyutu puanları ile müzik merkezinde geçirilen süre arasında ise negatif yönde, orta düzeyde anlamlı bir ilişki ( $\mathrm{r}=-, 482 ; \mathrm{p}<.05)$ saptanmıştır. Diğer alt boyutlar ve ölçek toplamı ile öğrenme merkezlerinde geçirilen süreler arasında anlamlı bir ilişkiye rastlanmamıştır.

Tablo 4 Çocukların sosyal beceri puanları ile öğrenme merkezlerinde birlikte bulundukları akran sayıları arasındaki pearson korelasyon testi sonuçları

\begin{tabular}{lccc}
\hline \multirow{2}{*}{ Ölçek toplamı ve alt boyutları } & \multicolumn{2}{c}{ Öğrenme Merkezlerinde Birlikte Bulunulan Akran Sayıları } \\
\cline { 2 - 4 } & $\mathrm{n}$ & $\mathrm{r}$ & $\mathrm{p}$ \\
\hline Başlangıç Becerileri & 25 & .170 & .416 \\
Akademik Beceriler & 25 & .489 & $.013^{*}$ \\
Arkadaşlık Becerileri & 25 & .364 & .074 \\
Duyguları Yönetme Becerileri & 25 & .198 & .343 \\
Ölçek Toplamı & 25 & .370 & .069 \\
\hline
\end{tabular}

${ }^{*} \mathrm{p}<.05$

Tablo 4 incelendiğinde çocukların 'Akademik Beceriler' alt boyut puanları ile öğrenme merkezinde birlikte bulundukları akran sayıları arasında pozitif yönde, orta düzeyde anlamlı bir ilişki (r=,489; $\mathrm{p}<.05)$ olduğu görülmektedir. Diğer alt boyutlar ve ölçek toplamı ile akran sayıları arasında anlamlı bir ilişkiye rastlanmamıştır.

Tablo 5 Çocukların sosyal beceri puanları ile oynamayı tercih ettikleri farklı öğrenme merkezlerinin sayısı arasındaki pearson korelasyon testi sonuçları

\begin{tabular}{llcc}
\hline \multirow{2}{*}{ Ölçek toplamı ve alt boyutları } & \multicolumn{2}{c}{ Tercih Edilen Farklı Öğrenme Merkezlerinin Sayısı } \\
\cline { 2 - 4 } & $\mathrm{n}$ & $\mathrm{r}$ & $\mathrm{p}$ \\
\hline Başlangıç Becerileri & 25 & -.131 & .533 \\
Akademik Beceriler & 25 & -.155 & .460 \\
Arkadaşlık Becerileri & 25 & -.388 & .055 \\
Duyguları Yönetme Becerileri & 25 & -.403 & $.045^{*}$ \\
Ölçek Toplamı & 25 & -.299 & .147 \\
\hline
\end{tabular}

${ }^{*} \mathrm{p}<.05$

Tablo 5'e göre; 'Duyguları Yönetme Becerileri' alt boyut puanları ile çocukların oynamayı tercih ettikleri farklı öğrenme merkezlerinin sayısı arasında negatif yönde, orta düzeyde anlamlı bir ilişki $(\mathrm{r}=-, 403 ; \mathrm{p}<.05)$ bulunmuştur. Diğer alt boyutlar ve tercih edilen farklı öğrenme merkezlerinin sayısı arasında anlamlı bir ilişkiye rastlanmamıştır. 


\section{SONUÇ ve TARTIŞMA}

Araştırmada bir okul öncesi eğitim kurumuna giden 56-72 aylık çocukların serbest oyun saatlerinde öğrenme merkezlerinde geçirdikleri haftalık ortalama süreler, merkezlerde birlikte bulundukları akran sayıları ve tercih edilen farklı öğrenme merkezlerinin sayısı değişkenleri ile sosyal becerileri arasında anlamlı ilişki olup olmadığı saptanmaya çalışılmıştır. Ayrıca öğrenme merkezlerinde geçirdikleri ortalama sürelerin cinsiyete ve yaşa göre değişip değişmediğine de bakılmıştır. Elde edilen sonuçlar aşağıda verilmiş ve tartışılmıştır.

Öğretmenlerin gözlemleri sonucunda çocukların en çok dramatik oyun ve blok merkezlerinde vakit geçirdikleri; bu merkezleri sırasıyla sanat merkezi, müzik merkezi, kitap merkezi ve fen merkezinin izlediği saptanmıştır. Ramazan, Arslan Çiftçi ve Tezel'in 2018 yılında yaptıkları çalışmaya göre okul öncesi öğretmenleri, çocukların en çok blok merkezi ve dramatik oyun merkezini tercih ettiklerini; müzik, kitap ve fen merkezlerinin ise çocuklar tarafından çok az tercih edildiğini belirtmiştir. Aysu ve Aral'ın (2016) çalışmasında da okul öncesi eğitim kurumlarında görev yapan öğretmenler yine bu üç merkezin çocuklar tarafindan çok az tercih edildiğini söylemişler; bu durumun nedeni olarak fen merkezi için fiziksel yetersizliği, kitap merkezi için ailelerden kitap okuma alışkanlığının edinilmemiş olmasını, müzik merkezi için çocukların ilgisinin olmamasını öne sürmüşlerdir. Aynı çalışmada araştırmacıların gözlemlerine göre; öğretmenlerin bu merkezlerden bazılarını tam yapılandırmadıkları, çocuklar öğrenme merkezlerinde vakit geçirirken öğretmenlerin onlara rehberlik etmedikleri ve onları yeterince yönlendirmedikleri sonucuna ulaşılmıştır. Ayrıca Erşan da (2011) yaptığı çalışmada sanat merkezi dışında müzik, fen-matematik ve kitap merkezlerinin materyal yetersizliği, öğretmen müdahalesi, materyallerin ulaşılır olmaması gibi nedenlerle çocukların ilgisini çekmediğini belirtmiştir.

Tercih edilen öğrenme merkezlerine cinsiyet değişkeni açısından bakıldığında kız ve erkek çocuklar arasında farklar bulunmuştru; kız çocukları en çok dramatik oyun merkezini tercih ederken, erkek çocuklar ise blok merkezini tercih etmektedir. Yapılan çalışmalarda da aynı sonuç bulunmuştur (Özyürek ve Kılınç 2015; Ramazan, Arslan Çiftçi ve Tezel, 2018). Yapılan çeşitli araştırmalarda kız ve erkek çocukların o merkezlerdeki oyuncaklarla oynamaktan keyif aldıkları için daha fazla tercih ettikleri belirlenmiştir (Özdemir, 2014; Sapsağlam, 2018; Todd, Barry ve Thommessen, 2016; Yağan Güder ve Alabay, 2016).

Tercih edilen öğrenme merkezleri yaş değişkeni açısından incelendiğinde 67-72 aylık büyük yaş grubunun en çok dramatik oyun merkezi ve blok merkezini tercih ettikleri görülmüsstür. 61-66 aylık çocuklar bu iki merkeze ilave olarak sanat merkezini de tercih etmektedir. 56-60 ay yaş grubundaki küçük çocuklar ise daha çok blok merkezinde oynamaktadır. 
Çocukların öğrenme merkezlerinde geçirdikleri süreler ile sosyal beceri puanları arasındaki ilişki incelendiğinde 'Başlangıç Becerileri' alt boyut puanları ile 'sanat' merkezinde geçirilen süre arasında pozitif yönde anlamlı bir ilişki olduğu bulunmuştur, yani sanat merkezinde geçirilen süre arttıkça başlangıç becerileri de artmaktadır. Birlikte bulunulan akran sayılarının daha fazla olduğu ve daha çok tercih edilen dramatik oyun merkezi ve blok merkezinde geçirilen süreler ile sosyal beceri puanları arasında ise anlamlı ilişki saptanamamıştır. Çocuğun sosyalleşmesinde akran kabulü ve popülarite önemli rol oynamaktadır; çocukların etkileşimlerindeki olumlu sosyal bildirimler, gruba dahil olmalarını ve bu yolla da sosyal becerilerini etkilemektedir (Michelson, Sugai, Wood ve Kazdin, 2013). Çocuklar, özellikle de erkek çocuklar dramatik oyunlarında agresif tutumlar sergileyebilmekte (Dunn ve Hughes, 2001; Jarvis, 2007; akt. Hart ve Tannock, 2013); bu tutumlar1 ve oyuncakları silah veya savaş aracı olarak kullanmaları bazı açılardan onları olumlu yönde etkilerken, çocukların birbirleri arasındaki ilişkilere fiziksel ve duygusal olarak zarar verebilmektedir (Hart ve Tannock, 2013). Bu bilgilere dayanarak Başlangıç Becerileri alt boyut puanları ile dramatik oyun merkezi ve blok merkezinde geçirilen süreler arasında negatif yönde anlamlı bir ilişki olması beklenirken tersine bir sonuç çıkmıştır. Bu sonucun, çocukların oyun sırasında sosyal ilişkilerini dengeli yönettiklerinin göstergesi olduğu söylenebilir.

Sanat merkezleri bakanlık tarafından çocukların farklı malzemelerle etkileşime geçtikleri bir merkez olarak tanımlanmakta (MEB, 2013); Özyürek ve Kılınç (2015) yaptıkları araştırmada çocukların en bağımsız olduğu üç merkezden birinin sanat merkezi olduğunu belirtmektedir. Çocukların sanat merkezlerinde daha çok boya, hamur gibi materyaller yoluyla birbirleriyle etkileşime geçtikleri, daha özgür ve bağımsız çalıştıkları görülmektedir. Blatt-Gross’a göre (2011), çocukların sanat etkinliklerinde ortak bir masada çalışmaları, malzemeleri dağıtmaları, birbirleriyle değiş tokuş etmeleri için iyi bir sosyal etkileşim gerekmektedir; çocuklar yaptıkları sanat etkinliklerinin renkleri ve şekilleri hakkında birbirleriyle uzun sohbetler etmek, arkadaşlanının malzemelerini kullanmak için izin istemek ve yapılan resimleri bazen birbirlerine hediye etmek gibi sosyal beceri açısından önemli göstergeleri sergiletmektedir. Benzer şekilde Arda da (2009) çocukların sanat etkinlikleri sırasında yeni arkadaşlıklar kurma, konuşmak için sırasını bekleme, paylaşma, işbirliği yapma, birbirine yardım etme gibi yollarla sosyal becerilerini geliştirdiklerini belirtmektedir.

Müzik merkezinde geçirilen süre ile 'Arkadaşlık Becerileri' alt boyut puanları arasında ters yönde anlamlı ilişki bulunmuştur, yani müzik merkezinde geçirilen süre arttıkça arkadaşlık becerileri azalmaktadır. Müzik merkezi, çocukların müzik ile ilgili ses, hareket ve ritim becerilerini arttırmaya yönelik etkinliklerin yapıldığı öğrenme merkezi olarak tanımlanmaktadır (Özdemir Beceren, 2016). 
Sığırtmaç (2002), müzik eğitiminin çocukların konuşmasında, birçok kavram ve konuyu öğrenmesinde ve vücudunu koordineli bir şekilde kullanmasında etkili olduğunu belirtmiştir. Özyürek ve Kılınç (2015) öğretmenlerle yaptıkları çalışma sonucunda müzik merkezinin çocuklar tarafından en az tercih edilen merkezlerden biri olduğunu belirtmiştir. Bu araştırmada da çocukların müzik merkezlerinde daha az vakit geçirdikleri, burada birlikte oldukları akran sayısının ve dolayısıyla akran etkileşimin daha az olduğu, materyallerle bireysel olarak daha çok vakit geçirdikleri görülmüştür. Bu nedenle Arkadaşlık Becerileri alt boyut puanlarının düşük olduğu söylenebilir.

Çocukların daha çok vakit geçirmeyi tercih ettikleri merkezlerdeki akran sayıları ile 'Akademik Beceriler' alt boyut puanları arasında pozitif yönde anlamlı bir ilişki tespit edilmiştir, yani çocukların en çok vakit geçirdikleri merkezlerdeki akran sayıları arttıkça, çocukların akademik becerileri de artmaktadır artış göstermektedir. Akademik beceriler; Ömeroğlu vd. (2014) tarafindan çocukların akademik becerilerini desteklemeye yönelik, onları ilköğretime hazırlayan ve uyumlarını kolaylaştıran beceriler olarak tanımlanmaktadır. Uyanık ve Kandır (2010), erken akademik becerileri okul öncesi dönem için kısaca okuma-yazma ve matematik becerileri olarak tanımlamakta; bu becerilerin sosyal beceriler açısından ise büyük kısmını dil ve iletişim becerileri kapsamaktadır. Vygotsky, dili bilişsel gelişim için bir araç olarak görmüş ve insanların birbirleriyle konuşarak ortak deneyimlerle öğrendiğini savunmuştur (Bodrova ve Leong, 2010). Dolayısıyla çocuğun katıldığ1 merkezlerdeki akran sayısı arttıkça çocuğun bu deneyimlere daha çok maruz kaldığı, bunun da akademik becerilerinin artmasında rol oynadığı söylenebilir. Ertürk Karaca, Ayrancı ve Kılıç (2016) yaptıkları çalışmada; çocukların aralarındaki konuşma ve dinleme becerilerinin, kurulan oyunlarla birlikte diyaloglarının ve ortak oyun planlamalarının serbest oyun sırasında arttığını belirtmişlerdir. Çocukların oynamayı tercih ettikleri öğrenme merkezlerinin sayısı ile 'Duyguları Yönetme Becerileri’ alt boyut puanları arasında negatif yönde anlamlı ilişki bulunmuştur, yani seçtikleri öğrenme merkezi sayısı arttıkça, duygularını yönetme becerileri azalmaktadır. Bunun sebebi olarak fazla sayıda öğrenme merkezi dolaşan çocukların tam olarak bir oyun grubuna dahil olamaması gösterilebilir. Ömeroğlu vd. (2014), duyguları yönetme becerilerini çocukların duygularını tanıma ve kontrol etme becerileri olarak tanımlamıştır. Özyürek ve Kılınç (2015)'nn çalışmasında öğretmenler, çocukların öğrenme merkezleri seçiminde orada arkadaşlarının olmasının önemli rol oynadığını belirtmiştir. Oyun gruplarına katılan çocuklar sosyal ortama uyum göstermekte; bunu yapabilmeleri için de pek çok sosyal ilişki biçimini öğrenmeleri gerekmektedirler (Özdoğan, 2014).

\section{Öneriler}

Yapılan çalışma sonucunda araştırmacılara ve alanda çalışan öğretmenlere yönelik öneriler: 
- Çalışma grubu genişletilerek aynı konuda daha geçerli ve güvenilir bulgular elde edilebilir.

- Okul öncesi dönem çocuklarının öğrenme merkezlerindeki etkinliklerinin dil gelişimi, motor gelişim, bilişsel gelişim gibi alanlar ve davranış problemleri ile olan ilişkisi incelenerek öğrenme merkezlerinin çocukların gelişiminde oynadığı rol ortaya konabilir.

- Bazı çalışmalarda yapılandırılmış programların çocukların sosyal beceri gelişimlerine etkisi bulunmuştur. Bu doğrultuda öğretmenlere öğrenme merkezlerinde çocuklar için daha yapılandırılmış etkinlikler hazırlamaları önerilebilir.

\section{KAYNAKÇA}

Acun Kapıkıran, N., Bora İvrendi, A., ve Adak, A. (2006). Okul öncesi çocuklanında sosyal beceri: Durum saptamasi. Pamukkale Üniversitesi Ë̈itim Fakültesi Dergisi, 19, 19-27. http://dergipark.ulakbim.gov.tr/pauefd/article/view/5000056242 adresinden alınd1.

Akfirat Önalan, F. (2006). Sosyal yeterlilik, sosyal beceri ve yaratıcı drama. Yaratıc Drama Dergisi, 1(1), 39-58.

Akkök, F. (2003). İlkögretimde sosyal becerilerin geliştirilmesi (Ögrretmen el kitabı). İstanbul: Özgür Yayınlar1.

Aktaş-Arnas, Y. (2018). Fiziksel ortamların planlanması. İçinde Y. Aktaş-Arnas ve F. Sadık (Ed.), Okul Öncesinde Sinnf Yönetimi (s. 48-60). Ankara: Pegem Akademi.

Aral, N., Kandır, A. ve Can-Yaşar, M. (2011). Okul öncesi eğitim ve okul öncesi eğitim programı İstanbul: Ya-Pa Yayınları.

Arda, Z. (2009). Art instruction in pre-school education. Procedia Socail and Behavioral Sciences, 1(1), $150-153$

Avcıoğlu, H. (2007). Sosyal Becerileri Değerlendirme Ölçeğinin geçerlik ve güvenirlik çalışması (46 Yaş). Abant İžet Baysal Üniversitesi Eğitim Fakültesi Dergisi, 7(2), 93-103.

Aysu, B. ve Aral, N. (2016). Okul öncesi öğretmenlerinin öğrenme merkezleri hakkındaki görüş ve uygulamalarının incelenmesi. Kastamonu Ë̆itim Dergisi, 24(5), 2561-2574.

Bennet, W. J., Finn Jr, C. E. ve Cirbb Jr, J. T. (2000). The educated child: A parent's guide from preschool through eight grade. New York: Touchstone.

Berk, L. E. (2013). Bebekler ve çocuklar: Doğum öncesinden orta Ç̧ocukluğa (7 b.). (N. Işıkoğlu Erdoğan, Çev.) Ankara: Nobel Yayıncilık.

Bierman, K. L., Coie, J. D., Dodge, K. A., Foster, E. M., Greenberg, M. T., Lochman, J. E., . . . Pinderhughes, E. E. (2004). The effects of the fast track program on serious problem outcomes at the end of elementary school. Journal of Clinical Child and Adolescent Psychology, 650 - 661. doi:10.1207/s15374424jccp3304_1 
Blatt-Gross, C. (2011). Understanding artful behavior as a human proclivity: Clues from a prekindergarten classroom. Journal of Learning Through The Arts, 7(1). n1

Bodrova, E. ve Leong, D. J. (2010). Zihnin araçlar: Erken çocukluk eğitiminde Vygotsky yaklassım. G. Haktanır (Ed.) Ankara: Anı Yayıncilı.

Büyüköztürk, Ş. (2018). Sosyal bilimler için veri analiæi el kitabı. Ankara: Pegem Akademi.

Büyüköztürk, Ş., K1lı̧ Çakmak, E., Akgün, Ö. E., Karadeniz, Ş. ve Demirel, F. (2018). Bilimsel araştırma yöntemleri. Ankara: Pegem Akademi.

Caldarella, P. ve Merrell, K. W. (1997). Common dimensions of social skills of children and adolescents: A taxonomy of positive behaviors. School Psychology Review, 26(2), 264-278.

Durualp, E. ve Aral, N. (2010). Altı yaşındaki çocukların sosyal becerilerine oyun temelli sosyal beceri eğitiminin etkisinin incelenmesi. Hacettepe Üniversitesi Eğitim Fakültesi Dergisi - H.U. Journal of Education, 39, 160-172.

Durualp, E. ve Aral, N. (2011). Oyun temelli sosyal beceri eğğtimi. Ankara: Vize Yayınc1l1k.

Eke, K. (2017). Okul öncesi dönemdeki çocukların öz düzenleme becerileri ile anne-baba tutumları arasındaki ilişkinin incelenmesi. International Journal of Eurasia Social Sciences, 8(28), 273-287.

Erşan, Ş. (2011). Okul öncesi eğitim kurumlarnnda görev yapan ögretmenlerin ilgi kösselerinde serbest oyun etkinlikleri ile ilgili görüss ve uygulamalarmm incelenmesi, Yayımlanmamış doktora tezi. Gazi Üniversitesi Eğitim Bilimleri Enstitüsü, Ankara.

Ertürk Karaca, H. G., Ayrancı, M. ve Kılıç, Ş. (2016). Anasınıflarında serbest oyun zamanında "oyun planlama" modelinin kullanılmasına ilişkin bir eylem araştırması. Uluslararası Sosyal Arastormalar Dergisi, 9(43), 1423-1431.

Gresham, F. ve Elliott, S. N. (1987). The relationship between adaptive behavior and social skills: Issues in definition and assesment. The Journal of Special Education, 21(1), 167-181.

Güleş, F. (2013). Okul öncesi eğitimde fiæịksel cevreye ilişkin kalite standartlarmm belirlenmesi, Yayınlanmamış doktora tezi. Selçuk Üniversitesi Sosyal Bilimler Enstitüsü, Konya.

Hart, J. L. ve Tannock, M. T. (2013). Young children's play fighting and use of war toys. Encyclopedia of Early Childhood Development, 1-16.

Ia Greca, A. M. ve Santogrossi, D. A. (1980). Social skills training with elementary schol students: A behavioral group approach. Journal of Consulting and Clinical Psychology, 48(2), 220-227.

Kara, Y. ve Çam, F. (2007). Yaratıcı drama yönteminin bazı sosyal becerilerin kazandırılmasına etkisi. Hacettepe Üniversitesi Eğitim Fakültesi Dergisi - H.U. Journal of Education, 32, 145-155.

Kazdin, A. E., Matson, J. L. ve Esveldt-Dawson, K. (1984). The relationship of role-play assessment of children's social skills to multiple measures of social competence. Behaviour Research and Therapy, 22(2), 129-139. doi:10.1016/0005-7967(84)90101-3 
Koçyiğit, S. (2016). Okul öncesi eğitimin tanımı, amacı, önemi ve ilkeleri. R. Zembat (Ed.) içinde, Okul Öncesi Eğitime Giriş (2 b., s. 18-19). Ankara: Hedef CS Yayıncılık.

Kramer, T. J., Caldarella, P., Christensen, L. ve Shatzer, R. H. (2009). Social and emotional learning in the kindergarten classroom: Evualion of the strong start curriculum. Early Childhood Education Journal, 37(4), 303-309.

Legoff, D. B. ve Sherman, M. (2006). Long-term outcome of social skills intervention based on interactive LEGO play. Journal of The National Autistic Society, 10(4), 317-329.

McClelland, M. M. ve Morrison, F. J. (2003). The emergence of learning-related social skills in preschool children. Early Childhood Research Quarterly, 3, 206-224. doi:10.1016/S08852006(03)00026-7

MEB. (2013). Milli Eğitim Bakanh̆̆g Genel Müdürlüğ̈̈ Okul Öncesi Eğitim Program. http://tegm.meb.gov.tr/dosya/okuloncesi/ooproram.pdf. adresinden alınd1

Michelson, L., Sugai, D. P., Wood, R. P. ve Kazdin, A. E. (2013). Social skills and child development. İçinde L. Michelson, D. P. Sugai, R. P. Wood, ve A. E. Kazdin. Social Skills Assessment And Training With Children: An Empirically Based Handbook. New York: Springer Science \& Business Media.

Mueller, E. ve Brenner, J. (1977). The origins of social skills and interaction among playgroup toddlers. Journal of Child Development, 48(3), 854-861.

O'Connor, C. ve Stagnitti, K. (2011). Play, behaviour, language and social skills: The comparison of a play and a non-play intervention within a specialist school setting. Research in Developmental Disabilities, 32(3), 1205-1211. doi:10.1016/j.ridd.2010.12.037

Ömeroğlu, E., Büyüköztürk, Ş., Aydoğan, Y., Çakan, M., Kılıç Çakmak, E., Özyürek, A., . . . Karayol, S. (2014). Okul Öncesi Sosyal Beceri Değerlendirme Ölçeği Öğretmen Formunun geliştirilmesi: Geçerlik ve güvenirlik analizleri. 21. Yüzyllda Ë̆itim ve Toplum - Education and Society In the 21st Century, 3(8), 37-46

Özdemir Beceren, B. (2016). Okul öncesi eğitim ortamları. İçinde R. Zembat (Ed.), Okul Öncesi Ë̆itime Giriş (180-199). Ankara: Hedef Yayıncilık.

Özdemir, S. (2014). 5-6 yaş çocukların serbest zaman etkinliklerindeki oyun ve oyuncak tercihlerinin incelenmesi. Journal of Educational Sciences, 2(2), 1-15.

Özdoğan, B. (2014). Çocuk ve oyun: Çocuğa oyunla yardım. Ankara: Anı Yayıncılık.

Özyürek, A. ve Kılınç, N. (2015). Okul öncesi eğitim kurumlarındaki öğrenme merkezlerinin çocukların serbest oyun davranışları üzerine etkisi. Karabük Üniversitesi Sosyal Bilimler Enstitüsü Dergisi, 5(2), 125-138.

Ramazan, O., Arslan Çiftçi, H. ve Tezel, M. (2018). Okul öncesi sınıflarındaki öğrenme merkezlerinin durumunun belirlenmesi ve öğretmenlerin öğrenme merkezleri hakkındaki görüşlerinin incelenmesi. Erkeen Cocukluk Çalsmalar Dergisi, 2(2), 213-233. 
Riggio, R. E. (1986). Assesment of basic social skills. Journal of Personality and Social Psychology. 51(3), 649.

Sapsağlam, Ö. (2018). Okul öncesi dönem çocuklarının değişen oyun tercihleri. Abi Evran Üniversitesi Kerşebir Eğitim Fakültesi Dergisi, 19(1), 1122-1235.

Sığırtmaç, A. (2002). Okul öncesi dönemde müzik eğitimi. Çukurova Üniversitesi Sosyal Bilimler Enstitüiü Dergisi, 9(9).

Spence, S. H. (2003). Social skills training with children and young people: Theory, evidence and practice. Journal of Child and Adolescent Mental Health, 8(2), 84-96. doi:10.1111/14753588.00051

Swindells, D. ve Stagnitti, K. (2006). Pretend play and parents' view of social competence: The construct validity of the Child-Initiated Pretend Play Assesment. Australian Occupational Therapy Journal, 53(4). 314-324.

Todd, B. K., Barry, J. A. ve Thommessen, S. A. (2016). Preferences for 'gendertyped' toys in boys and girls aged 9 to 32 months. Infant and Child Development. 26(3), 1-14

Trawick-Smith, J. (2013). Erken çocukluk döneminde gelişim: Çok kültürlü bir bakııs açısı. A. Berrin (Ed.) Ankara: Nobel Akademik Yayıncilı.

Tunçeli, H. İ. ve Akman, B. (2014). Anaokullarına devam eden 6 yaş çocuklarının sosyal becerilerinin okul olgunluğuna etkilerinin incelenmesi. Ĕ̈itim ve Öğretim Arastırmalar Dergisi - Journal of Education and Teaching, 3(4), 333-341.

Uyanık, Ö. ve Kandır, A. (2010). Okul öncesi dönemde erken akademik beceriler. Kuramsal Ë̆itimbilim, 3(2), 118-134.

Yağan Güder, S. ve Alabay, E. (2016). 3-6 yaş arasındaki çocukların oyuncak tercihlerinin toplumsal cinsiyet bağlamında incelenmesi. Abi Evran Üniversitesi Kırşehir Eğitim Fakültesi Dergisi, 17(2), 91-111.

Yüksel, G. (1998). Sosyal Beceri Envanterinin Türkçe'ye uyarlanmas1: Geçerlik ve güvenirlik çalışmaları. Psikolojïk Damıșa ve Rebberlik Dergisi, 2(9), 39-48.

Zembat, R. (2001). Nitelike açıcından okul öncesi kurumlar ve ilgili bir araștırma. İstanbul: Marmara Üniversitesi Yayınları. 